\title{
Lords defeat for government on academic freedom clause
}

\section{London}

BRITISH academics are savouring a second significant victory in defence of university autonomy. Last week in the House of Lords, the government failed to defeat an opposition amendment to the education reform bill giving statutory protection to academic freedom. In its original form, the bill, which is likely to become law in the summer, proposes that governmentappointed parliamentary commissioners will rewrite university charters and statutes to abolish tenure and to enable staff to be dismissed "by reason of redundancy" or "for good cause". The implications of such a provision were seen as particularly insidious when considered in relation to other proposals (since modified) giving the government powers to direct the funding of individual departments within institutions. Despite sustained protest, much of it from the government's own supporters, the government has argued that it is impossible to draft a safeguard of academic freedom that would not be open to abuse.

Last week's successful amendment, put forward by Lord Jenkins of Hillhead, chancellor of the University of Oxford, would ensure that "academic staff have freedom within the law to question and test received wisdom, and to put forward new ideas and controversial and unpopular opinions, without placing themselves in jeopardy of losing their jobs or privileges that they may have at their institutions". The peers voted by 152 to 126 in favour of the amendment. Although the government is able technically to throw out the amendment when the bill returns to the House of Commons, the majority is seen as sufficiently convincing to make such a rejection unlikely. The wording of the amendment was originally put forward by the Committee of Vice-Chancellors and Principals several months ago, and was in essence accepted by the Education Secretary Kenneth Baker. Ironically, Baker is now said to be unhappy with the wording of the amendment.

The government has clearly failed to gauge the strength of feeling on its attempts to interfere with the running of the universities. It had ample opportunity to avoid the embarrasment of a defeat in the House of Lords. For more than six months the vice-chancellors have been meeting with government representatives to try to resolve the question of academic freedom, but with no sign of progress. The government's view has been that a comprehensive grievance procedure for dismissed academics would be sufficient to safeguard an individual's intellectual freedom.
The concessions the government will now be forced to make in response to last week's vote in the Lords will be the second major climbdown on the higher education aspects of the bill. Three months ago, when the bill was being considered by the Commons standing committee on education, Baker bowed to pressure and agreed to a number of important concessions on the government's powers to intercede in the financing and management of higher education (see Nature 331, 645; 1988).

Simon Hadlington

\section{More ECUs to spend}

THE Council of the European Communities last month approved two projects SCIENCE and DELTA - that aim to promote exchange and training facilities for European researchers. Carrying on from the previous Stimulation Programme, SCIENCE aims to create a network of exchange and co-operation between European laboratories and to facilitate visits by young researchers to other European laboratories. With a budget of 167 million ECU $(1 \mathrm{ECU}=£ 0.69)$ for the period 1988-92, the programme will help over 8,000 researchers working in the exact and natural sciences.

DELTA, which will be complementary to the existing COMETT educational programme, is to develop and exploit new educational technologies, based around information technology, telecommunications and broadcasting. With a preliminary budget of $\mathbf{2 0}$ million ECU for an 18-month trial period, DELTA aims to encourage the development of norms in both technology and curriculum for Europe-wide educational programmes.

P.C.

\section{Quick is beautiful}

Although giant budgets and years of planning have recently been the norm for most on-orbit projects of the US National Aeronautics and Space Administration (NASA), there is a new theme being heard around the agency: 'Quick is beautiful'. 'QIB', as the philosophy is known at NASA, would be especially appropriate for the space station, according to a study group assigned to look into the topic. Payloads that require minimal amounts of power, communications capacity and/or human attention would be extremely useful for graduate students in space science or small companies anxious for 'proof of concept' data. The study group recommends that NASA create a management structure for QIB projects, and that five per cent of total space station resources be devoted to QIB research.
Natural History Museum in a decline?

\section{London}

CONCERN about the future of research in Britain's principal museum for the natural sciences has been rekindled with the announcement that active research is to cease in three areas. Declining government support in recent years has resulted in financial stringency and low morale among researchers at the British Museum (Natural History). Last month, following an external peer review, the museum authorities announced that research at the subdepartment of ornithology, at Tring in Hertfordshire, was to finish, with the two individuals affected being relocated elsewhere in the museum. Research into arachnids and coelenterates is also to be discontinued. Again, individuals affected will be relocated.

The British Ornithologists' Union has deplored the decision to pull out of bird research. It points out that since 1980 the number of staff at the ornithology subdepartment has been reduced from eleven to six, and that once the new proposals are implemented, together with an impending retirement, all that will remain will be three junior staff "lacking any qualifications to carry on the other functions of the subdepartment."

The decision to cut back on some areas of research comes at a time when ministers and museum officials are considering a confidential report from the Programme

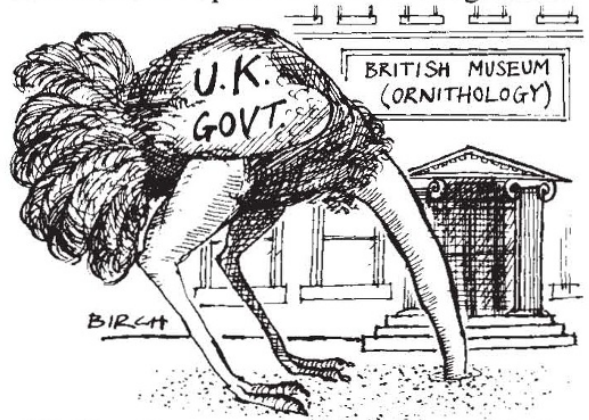

of Policy Research in Science and Technology (PREST), which draws attention to the level of despondency among the scientific staff and concludes that major changes in the museum's policy will be necessary to avoid long-term decline.

Museum officials are keen to point out that no direct cost savings will result from the latest moves, and that no redundancies have been made. The decision was taken essentially on scientific grounds, for more efficient deployment of expertise within limited resources.

Simon Hadlington

- The debate over museum cutbacks continues - see Correspondence, page 292 